Article

\title{
Initial Investigation into the Leaching of Manganese from Nodules at Room Temperature with the Use of Sulfuric Acid and the Addition of Foundry Slag-Part I
}

\author{
Norman Toro ${ }^{1}$, Nelson Herrera ${ }^{1}$, Jonathan Castillo ${ }^{2}$, Cynthia M. Torres ${ }^{1, *}$ and \\ Rossana Sepúlveda ${ }^{2}$ \\ 1 Departamento de Ingeniería en Metalurgia y Minas, Universidad Católica del Norte, Antofagasta 1270709, \\ Chile; ntoro@ucn.cl (N.T.); nelson.herrera@ucn.cl (N.H.) \\ 2 Departamento de Ingeniería en Metalurgia, Universidad de Atacama, Copiapó 1531772, Chile; \\ jonathan.castillo@uda.cl (J.C.); rossana.sepulveda@uda.cl (R.S.) \\ * Correspondence: cynthia.torres@ucn.cl; Tel: +56-552651022
}

Received: 24 October 2018; Accepted: 28 November 2018; Published: 3 December 2018

\begin{abstract}
In this study, the surface optimization methodology was used to assess the effect of three independent variables—-time, particle size and sulfuric acid concentration—on Mn extraction from marine nodules during leaching with $\mathrm{H}_{2} \mathrm{SO}_{4}$ in the presence of foundry slag. The effect of the $\mathrm{MnO}_{2} / \mathrm{Fe}$ ratio and particle size $\left(\mathrm{MnO}_{2}\right)$ was also investigated. The maximum $\mathrm{Mn}$ extraction rate was obtained when a $\mathrm{MnO}_{2}$ to Fe molar ratio of $0.5,1 \mathrm{M}$ of $\mathrm{H}_{2} \mathrm{SO}_{4},-320+400$ Tyler mesh $(-47+38 \mu \mathrm{m})$ nodule particle size and a leaching time of $30 \mathrm{~min}$ were used.
\end{abstract}

Keywords: manganese nodules; leaching; secondary mining; slag

\section{Introduction}

Oceans cover almost three-quarters of the Earth's surface and contain nine-tenths of its water, while being the habitat for $97 \%$ of the living things on the planet. Oceans are an essential part of the biosphere, influencing climate, health and wellbeing. Ocean sea beds comprise more than $60 \%$ of the earth's surface and contain great wealth, either in the form of Fe-Mn crust or Mn nodules [1].

Polymetallic nodules, also called manganese nodules, are rock concretions formed by concentric layers of Fe and Mn hydroxides. These polymetallic ores are a suitable alternative source of base metals for the growing manganese demand for steel production since high-grade ores are being depleted [2]. They were first discovered in the Siberian Arctic Ocean in 1968 [3]. Since then, new hydrometallurgical methods have been developed to extract valuable metals from nodules, including the use of sulfuric acid as an oxidation agent and other additives as reducing agents to extract manganese. Reductants such as iron from pyrite ore [4,5], ferrous ions [6] and wastewater from molasses-based alcohol production have been used [7]. Based on previous investigations, the advantages of iron as a reducing agent are its abundance, low cost and apparent efficiency [4-6,8].

Bafghi et al. [8] investigated the effect of elemental Fe (sponge iron at $\mu \mathrm{m}-600+250,-250+150$ ) as a reducing agent at different iron to $\mathrm{MnO}_{2}$ molar ratios $(0.67,0.80,1.0,1.2)$, and different acid to $\mathrm{MnO}_{2}$ molar ratios $(2.0,2.4,3.0)$ with a particle size of $-600+250 \mu \mathrm{m}$ and $-250+150 \mu \mathrm{m}$ of manganese ore. Considerable Mn extraction rates (98\%) were obtained at room temperature and for short leaching periods (20 min). They concluded that the most important variables for extracting $\mathrm{Mn}$ from nodules are the Fe concentration and nodule particle size. They also compared their results with those of Zakeri et al. [6], noting that sponge iron performs better as a reducing agent than ferrous ions. 
Kanungo and Das [9] conducted leaching tests of marine nodules in different acidic media. They obtained the maximum Mn extraction rates $(100 \%)$ with concentrated $\mathrm{HCl}\left(11 \mathrm{~mol} \cdot \mathrm{dm}^{-3}\right)$ at $90-100{ }^{\circ} \mathrm{C}$. Other studies report positive results for Mn extraction from marine nodules during leaching with $\mathrm{HCl}$, with the co-dissolution of considerable amounts of $\mathrm{Cu}$ (II), $\mathrm{Ni}$ (II) and $\mathrm{Co}$ (II) $[10,11]$.

Han et al. [12] conducted reactor-based leaching tests of marine nodules with sulfuric acid, and observed that low levels of manganese recovery (1\%) were obtained with $\mathrm{H}_{2} \mathrm{SO}_{4}$ at room temperature $\left(25^{\circ} \mathrm{C}\right)$. They concluded that high temperature is required during the leaching of marine nodules in order to improve recovery, selectivity and kinetics. This indicates the need to use a reducing agent to obtain good results, since manganese oxides like pyrolusite are relatively insoluble in conventional leaching media [13].

Reducing agents such as $\mathrm{SO}_{2}$ [14], pyrite iron [4,5], ferrous ions [6], molasses-based alcohol wastewater [7], $\mathrm{H}_{2} \mathrm{O}_{2}$ [15] and hydroxylammonium chloride [16] have been used to increase leaching kinetics.

Several authors have investigated Mn extraction from nodules during leaching with the use of sulfuric acid at different temperature in the presence of magnetite (1) and illite (2) marine nodules [17-21]. The most important reactions are shown below. These reactions indicate the important role of iron in extracting manganese in acidic environments.

$$
\begin{gathered}
{\left[\mathrm{Fe}^{2+} \mathrm{Fe}_{2}{ }^{3+}\right] \mathrm{O}_{4}(\mathrm{~s})+2 \mathrm{H}^{+}(\mathrm{aq})=\left[\mathrm{Fe}_{2}{ }^{3+}\right] \mathrm{O}_{3}+\mathrm{Fe}^{2+}(\mathrm{aq})+\mathrm{H}_{2} \mathrm{O}(\mathrm{l})} \\
3\left[\mathrm{Fe}^{2+} \mathrm{Ti}_{3}(\mathrm{~s})+6 \mathrm{H}^{+}(\mathrm{aq})=3\left[\mathrm{Ti}^{\mathrm{O}} \mathrm{O}_{2}+3 \mathrm{Fe}^{2+}(\mathrm{aq})+3 \mathrm{H}_{2} \mathrm{O}(\mathrm{l})\right.\right. \\
\mathrm{Fe}_{2} \mathrm{O}_{3}+\mathrm{H}_{2} \mathrm{SO}_{4}=\mathrm{Fe}_{2}\left(\mathrm{SO}_{4}\right)_{3}+\mathrm{H}_{2} \mathrm{O}(\mathrm{l}) \\
\mathrm{Fe}_{3} \mathrm{O}_{4}(\mathrm{~s})+4 \mathrm{H}_{2} \mathrm{SO}_{4}(\mathrm{aq})=\mathrm{FeSO}_{4}+\mathrm{Fe}_{2}\left(\mathrm{SO}_{4}\right)_{3}+4 \mathrm{H}_{2} \mathrm{O}(\mathrm{l}) \\
\mathrm{Fe}_{2}\left(\mathrm{SO}_{4}\right)_{3}+\mathrm{H}_{2} \mathrm{O}=\mathrm{Fe}(\mathrm{OH})_{3}+\mathrm{Fe}(\mathrm{s})+\mathrm{H}_{2}(\mathrm{aq})+\mathrm{H}_{2} \mathrm{SO}_{4}(\mathrm{aq})+\mathrm{O}_{2} \\
\mathrm{FeSO}_{4}(\mathrm{~s})+\mathrm{H}_{2} \mathrm{O}(\mathrm{aq})=\mathrm{Fe}(\mathrm{s})+\mathrm{H}_{2} \mathrm{SO}_{4}(\mathrm{aq})+\mathrm{O}_{2} \\
\mathrm{MnO}_{2}(\mathrm{~s})+\mathrm{Fe}^{2+}(\mathrm{aq})+\mathrm{H}^{+}(\mathrm{aq})=\mathrm{Fe}^{3+}(\mathrm{aq})+\mathrm{Mn}^{2+}(\mathrm{aq})+\mathrm{H}_{2} \mathrm{O}(\mathrm{l}) \\
\mathrm{MnO}_{2}(\mathrm{~s})+\mathrm{Fe}(\mathrm{s})+8 \mathrm{H}^{+}(\mathrm{aq})=2 \mathrm{Fe}^{3+}(\mathrm{aq})+\mathrm{Mn}^{2+}(\mathrm{aq})+2 \mathrm{H}_{2} \mathrm{O}(\mathrm{l})+2 \mathrm{H}_{2}(\mathrm{~g}) \\
\mathrm{MnO}_{2}(\mathrm{~s})+2 / 3 \mathrm{Fe}(\mathrm{s})+4 \mathrm{H}^{+}(\mathrm{aq})=\mathrm{Mn}^{2+}(\mathrm{aq})+2 / 3 \mathrm{Fe}^{3+}(\mathrm{aq})+2 \mathrm{H}_{2} \mathrm{O}(\mathrm{l})
\end{gathered}
$$

The present study investigates the extraction of manganese from marine nodules in an acid medium $\left(\mathrm{H}_{2} \mathrm{SO}_{4}\right)$ at room temperature using smelter slag as a source of iron. Currently in Chile, approximately $80 \mathrm{t}$ of tailings and $1.8 \mathrm{t}$ of smelter slag are generated during the production of one ton of copper. According to the Chilean National Service of Geology and Mining [22], there are 740 tailing dams in the country, of which 469 are inactive and 170 are abandoned. The volume of generated tailings increased by $213.8 \%$ from 2000 to 2016 [23].

\section{Materials and Methods}

\subsection{Manganese Nodule Sample}

The marine nodules used in this research were collected in the 1970s from the Blake Plateau in the Atlantic Ocean. The nodules were ground in a porcelain mortar to sizes ranging from -140 to $+100 \mu \mathrm{m}$. The ground samples were analyzed by atomic emission spectrometry via induction-coupled plasma (ICP-AES), in the applied geochemistry laboratory of the Department of Geological Sciences of the Universidad Católica del Norte. Table 1 shows the chemical composition of the samples. 
Table 1. Chemical analysis of the manganese ore.

\begin{tabular}{ccccc}
\hline Component & Mn & Fe & Cu & Co \\
\hline Mass $(\%)$ & 15.96 & 0.45 & 0.12 & 0.29 \\
\hline
\end{tabular}

Table 2 shows the results of the elemental characterization of the manganese-iron nodules. The sample material was analyzed using Bruker ${ }^{\circledR}$ M4-Tornado $\mu$-FRX table-top equipment (Fremont, CA, USA). $\mu$-XRF data interpretation shows that the nodules were composed of pre-existing nodule fragments that formed their core, with concentric layers that precipitated around the core at later stages. The experiments showed that pyrolusite $\left(\mathrm{MnO}_{2}\right)$ was the predominant phase.

Table 2. Mineralogical analysis of the manganese ore.

\begin{tabular}{ccccccccccc}
\hline Component & $\mathbf{M g O}$ & $\mathrm{Al}_{2} \mathrm{O}_{3}$ & $\mathrm{SiO}_{2}$ & $\mathbf{P}_{\mathbf{2}} \mathrm{O}_{5}$ & $\mathrm{SO}_{3}$ & $\mathrm{~K}_{2} \mathrm{O}$ & $\mathrm{CaO}$ & $\mathrm{TiO}_{2}$ & $\mathbf{M n O}_{2}$ & $\mathrm{Fe}_{2} \mathrm{O}_{3}$ \\
\hline Mass (\%) & 3.54 & 3.69 & 2.97 & 7.20 & 1.17 & 0.33 & 22.48 & 1.07 & 29.85 & 26.02 \\
\hline
\end{tabular}

\subsection{Smelter Slag}

The reducing agent (iron) was obtained in the form of slag from the Altonorte smelting plant. The same methods were used to determine the chemical and mineralogical composition of the slag as those used with the manganese nodules. Figure 1 shows the chemical species using QEMSCAN, several iron-containing phases are present while the content of Fe is estimated at $37.52 \%$.

MODAL MINERALOGY

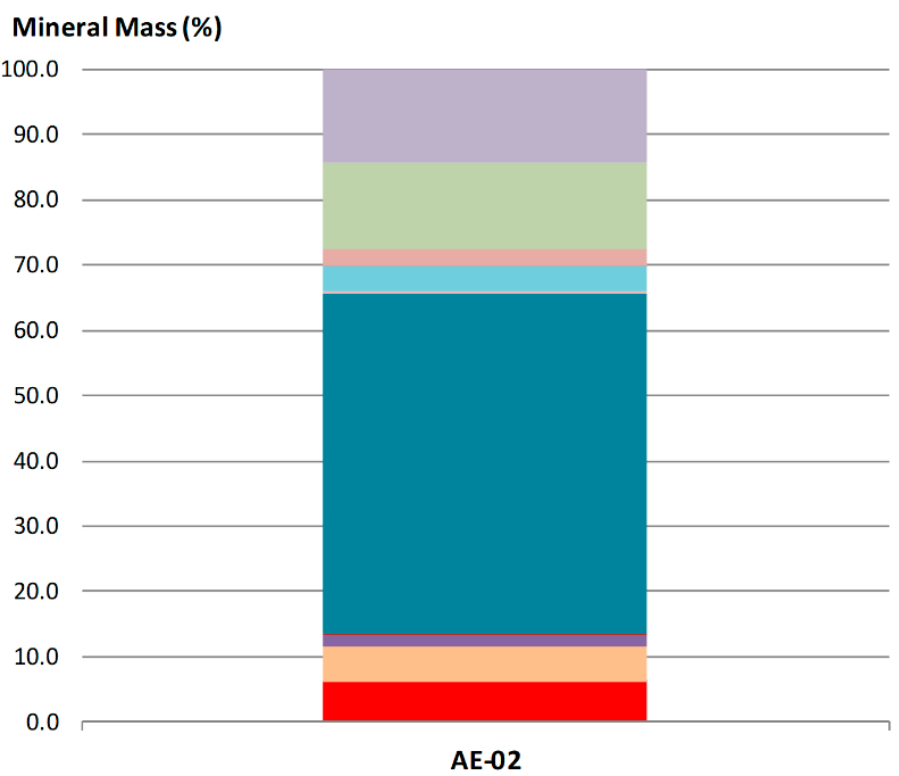

Figure 1. Detailed modal mineralogy.

\author{
Others \\ Other Phyllosilicates \\ - Chlorite/Biotite \\ - Tourmaline Group \\ - Jarosite \\ - Siderite \\ - Ilmenite/Titanite/Rutile \\ - Hematite \\ Specular Hematite \\ nagnetite \\ - Pyrite \\ - Cu-Fe Hydroxides \\ - Other Cu Minerals \\ - Tennantite/Tetraedrite \\ - Chalcopyrite/Bornite
}

Table 3 shows the mineralogical composition of the slag. The Fe in the slag was mainly in the form of magnetite. 
Table 3. The mineralogical composition of the slag as determined by QEMSCAN.

\begin{tabular}{cc}
\hline Mineral & Amount $\%$ w/w \\
\hline Chalcopyrite/bornite & 6.05 \\
Tennantite/tetraedrite & 0.24 \\
Other Cu minerals & 5.22 \\
Cu-Fe hydroxides & 1.80 \\
Pyrite & 0.18 \\
Magnetite & 52.11 \\
Specular hematite & 0.47 \\
Hematite & 3.79 \\
Ilminite/titanite/rutile & 0.03 \\
Siderite & 0.07 \\
Chlorite/biotite & 2.55 \\
Other phyllosilicates & 13.14 \\
Others & 14.35 \\
Total & 100.00 \\
\hline
\end{tabular}

\subsection{Reagent and Leaching Test}

The sulfuric acid used for the leaching tests was grade P.A., with a 95-97\% purity, a density of $1.84 \mathrm{~kg} / \mathrm{L}$ and a molecular weight of $98.8 \mathrm{~g} / \mathrm{mol}$.

Leaching tests were carried out in a $50 \mathrm{~mL}$ glass reactor with a $0.01 \mathrm{~S} / \mathrm{L}$ ratio of leaching solution. A total of $200 \mathrm{mg}$ of $\mathrm{Mn}$ nodules were maintained in agitation and suspension with the use of a 5-position magnetic stirrer (IKA ROS, CEP 13087-534, Campinas, Brasil) at a speed of $600 \mathrm{rpm}$. The tests were conducted at room temperature of $25^{\circ} \mathrm{C}$, with variations in additives, particle size and leaching time.

\subsection{Experimental Design}

The effects of independent variables on the Mn extraction rates from manganese nodules were studied using the response surface optimization method [24,25]. The central composite face (CCF) design and a quadratic model were applied to the experimental design.

Twenty-seven experimental tests were carried out to study the effects of $\mathrm{H}_{2} \mathrm{SO}_{4}$ concentration, particle size and time as dependent variables. Minitab 18 software was used for modeling and experimental design, which allowed for the study of the linear and quadratic effects of the independent variables. The experimental data were adjusted by a multiple regression analysis [26] to a quadratic model, considering only those factors that helped to explain the variability of the model.

Slag was used for all the tests and the experimental model, thus the $\mathrm{MnO}_{2}$ and Fe ratio was 1 molar. Table 4 shows the experimental parameters for the central composite face design and data for $\mathrm{Mn}$ from $\mathrm{H}_{2} \mathrm{SO}_{4}$ extraction optimization.

The general form of the experimental model is represented by:

$$
\begin{gathered}
Y=(\text { overall constant })+(\text { linear effects })+(\text { interaction effects })+(\text { curvature effects }) \\
Y=b_{0}+b_{1} x_{1}+b_{2} x_{2}+b_{3} x_{3}+b_{12} x_{1} x_{2}+b_{13} x_{1} x_{3}+b_{23} x_{2} x_{3}+b_{11} x_{1}^{2}+b_{22} x_{2}^{2}+b_{33} x_{3}^{2}
\end{gathered}
$$

where $x_{1}$ is time; $x_{2}$ is mesh size; $x_{3}$ is $\mathrm{H}_{2} \mathrm{SO}_{4}$ concentration, and $b$ is the variable coefficients.

Table 4 presents the ranges of parameter values used in the experimental model. The variable values were codified in the model. Equation (11) transforms a real value $\left(Z_{i}\right)$ into a coded value $\left(X_{i}\right)$ according to the experimental design:

The Equation (11) coded value was found as follows:

$$
X_{i}=\frac{Z_{i}-\frac{Z_{\text {high }}+Z_{\text {low }}}{2}}{\frac{Z_{\text {high }}-Z_{\text {low }}}{2}}
$$


where $Z_{\text {high }}$ and $Z_{\text {low }}$ are respectively the highest and lowest level of a variable [27].

Table 4. Experimental configuration and Mn extraction data.

\begin{tabular}{cccccc}
\hline Exp. No. & Time (min) & $\begin{array}{c}\text { Sieve Fraction } \\
\text { (Tyler Mesh) }\end{array}$ & $\begin{array}{c}\text { Particle Size } \\
(\boldsymbol{\mu} \mathbf{m})\end{array}$ & $\begin{array}{c}\text { Sulphuric } \\
\text { Acid }(\mathbf{M})\end{array}$ & $\begin{array}{c}\text { Mn Extraction } \\
\mathbf{( \% )}\end{array}$ \\
\hline 1 & 10 & $-200+270$ & $-75+53$ & 0.1 & 8.77 \\
2 & 20 & $-100+140$ & $-150+106$ & 0.5 & 30.08 \\
3 & 20 & $-200+270$ & $-75+53$ & 1.0 & 58.27 \\
4 & 30 & $-200+270$ & $-75+53$ & 1.0 & 69.55 \\
5 & 10 & $-320+400$ & $-47+38$ & 0.5 & 22.56 \\
6 & 20 & $-100+140$ & $-150+106$ & 0.1 & 11.28 \\
7 & 30 & $-100+140$ & $-150+106$ & 1.0 & 57.64 \\
8 & 30 & $-320+400$ & $-47+38$ & 0.1 & 15.04 \\
9 & 10 & $-100+140$ & $-150+106$ & 0.5 & 16.92 \\
10 & 10 & $-100+140$ & $-150+106$ & 1.0 & 38.22 \\
11 & 20 & $-200+270$ & $-75+53$ & 0.5 & 53.88 \\
12 & 30 & $-100+140$ & $-150+106$ & 0.1 & 11.90 \\
13 & 20 & $-200+270$ & $-75+53$ & 0.1 & 17.54 \\
14 & 10 & $-100+140$ & $-150+106$ & 0.1 & 6.27 \\
15 & 10 & $-200+270$ & $-75+53$ & 1.0 & 45.74 \\
16 & 10 & $-320+400$ & $-47+38$ & 0.1 & 8.15 \\
17 & 20 & $-320+400$ & $-47+38$ & 0.1 & 10.65 \\
18 & 20 & $-320+400$ & $-47+38$ & 0.5 & 27.57 \\
19 & 30 & $-200+270$ & $-75+53$ & 0.1 & 20.05 \\
20 & 30 & $-200+270$ & $-75+53$ & 0.5 & 60.78 \\
21 & 10 & $-320+400$ & $-47+38$ & 1.0 & 44.49 \\
22 & 20 & $-320+400$ & $-47+38$ & 1.0 & 55.14 \\
23 & 20 & $-100+140$ & $-150+106$ & 1.0 & 49.50 \\
24 & 30 & $-320+400$ & $-47+38$ & 0.5 & 35.09 \\
25 & 10 & $-200+270$ & $-75+53$ & 0.5 & 39.47 \\
26 & 30 & $-320+400$ & $-47+38$ & 1.0 & 61.40 \\
27 & 30 & $-100+140$ & $-150+106$ & 0.5 & 35.09 \\
\hline
\end{tabular}

The statistical $R^{2}, R^{2}$ (pred), p values and Mallows's $C p$ indicate whether the model obtained is adequate to describe Mn extraction under a given domain. The $\mathrm{R}^{2}$ coefficient is a measure of the goodness of fit, that is, it measures the proportion of total variability of the dependent variable with respect to its mean, which is explained by the regression model. The $\mathrm{p}$ values represent statistical significance, which indicates whether there is a statistically significant association between the response variable and the term. The predicted $R^{2}$ was used to determine how well the model predicts the response for new observations. Finally, Mallows's $\mathrm{Cp}$ is a precise measure in the model, estimating the true parameter regression [27].

\section{5. $\mathrm{MnO}_{2} /$ Fe Ratio Effect}

The experimental design was used to assess the interaction among the sulfuric acid concentration, manganese nodule particle size and leaching time, with foundry slag as an additive. Bafghi et al. [8] conducted experiments with sponge iron at different $\mathrm{MnO}_{2} / \mathrm{Fe}$ ratios in acid media, and concluded that the amount of sponge iron is more crucial for manganese dioxide leaching than the sulfuric acid concentration. Zakeri et al. [6] concluded that the excess amounts of ferrous ions with reference to the $\mathrm{Fe}^{2+} / \mathrm{MnO}_{2}$ stoichiometric molar ratio of 3 was crucial for successful manganese dissolution.

In the present study, the effect of the $\mathrm{MnO}_{2} / \mathrm{Fe}$ ratio was evaluated with the use of foundry slag over time. A particle size of $-200+270$ Tyler mesh $(-75+53 \mu \mathrm{m})$, with a stirring speed of $600 \mathrm{rpm}$ and $20 \mathrm{~mL} 1 \mathrm{M}$ sulfuric acid concentration, and $200 \mathrm{mg}$ of Mn nodules were used at a room temperature $\left(25^{\circ} \mathrm{C}\right)$. 


\subsection{The Effect of Particle Size}

The effect of the manganese nodule particle size was evaluated by adding Fe slag at different sulfuric acid concentrations over time under the conditions shown in Table 5.

Table 5. Experimental conditions for the study of the effect of manganese nodule particle size.

\begin{tabular}{cc}
\hline Parameters & Values \\
\hline Sieve fraction (Tyler mesh) & $-100+140,-200+270,-320+400$ \\
Particle size $(\mu \mathrm{m})$ & $-150+106,-75+53,-47+38$ \\
Time (in min) & $5,10,20,30,40$ \\
$\mathrm{H}_{2} \mathrm{SO}_{4}(\mathrm{M})$ & $0.1,0.5,0.75,1$ \\
$\mathrm{MnO}_{2} / \mathrm{Fe}(\mathrm{slag})$ & $1 / 1$ \\
\hline
\end{tabular}

\section{Results and Discussion}

\subsection{Methodology}

An ANOVA analysis (Table 6) showed no significant effect of the interactions (time, particle size) and \{particle size, concentration\} $(p>0.05)$ on the manganese extraction rate. However, the interaction \{time, concentration\} must also be considered $(p<0.1)$. The effects of the curvature of time and concentration are not significant in explaining the variability of the model.

Table 6. ANOVA Mn extraction.

\begin{tabular}{|c|c|c|}
\hline Source & F-Value & $p$-Value \\
\hline Regression & 38.11 & 0.000 \\
\hline Time & 36.29 & 0.000 \\
\hline Mesh size & 26.95 & 0.000 \\
\hline $\mathrm{H}_{2} \mathrm{SO}_{4}$ & 269.22 & 0.000 \\
\hline Time $\times$ Mesh size & 0.51 & 0.485 \\
\hline Time $\times \mathrm{H}_{2} \mathrm{SO}_{4}$ & 3.89 & 0.065 \\
\hline Mesh size $\times \mathrm{H}_{2} \mathrm{SO}_{4}$ & 0.37 & 0.549 \\
\hline Time $\times$ Time & 0.62 & 0.443 \\
\hline Mesh size $\times$ Mesh size & 3.28 & 0.088 \\
\hline $\mathrm{H}_{2} \mathrm{SO}_{4} \times \mathrm{H}_{2} \mathrm{SO}_{4}$ & 1.86 & 0.191 \\
\hline
\end{tabular}

The linear effects of time and $\mathrm{H}_{2} \mathrm{SO}_{4}$ concentration contributed greatly to explaining the experimental model, as shown in the contour plot in Figure 2.

Figures 3-5 show that time, size range and $\mathrm{H}_{2} \mathrm{SO}_{4}$ concentration, as well as the interaction of time and $\mathrm{H}_{2} \mathrm{SO}_{4}$, and particle size curvature significantly affected the Mn extraction.

Equation (12) presents the Mn extraction model over the range of experimental conditions after eliminating the non-significant coefficients.

$$
\% \text { Extraction }=0.3112+0.0755 X_{1}+0.0651 X_{2}+0.2057 X_{3}+0.0303 X_{1} X_{3}-0.0393 X_{2}^{2}
$$

where $x_{1}, x_{2}$ and $x_{3}$ are coded variables that respectively represent time, particle size and $\mathrm{H}_{2} \mathrm{SO}_{4}$ concentration.

Figure 6 graphically represents the order in which parameters were added to the model, with the contribution of each variable to explaining variability. 


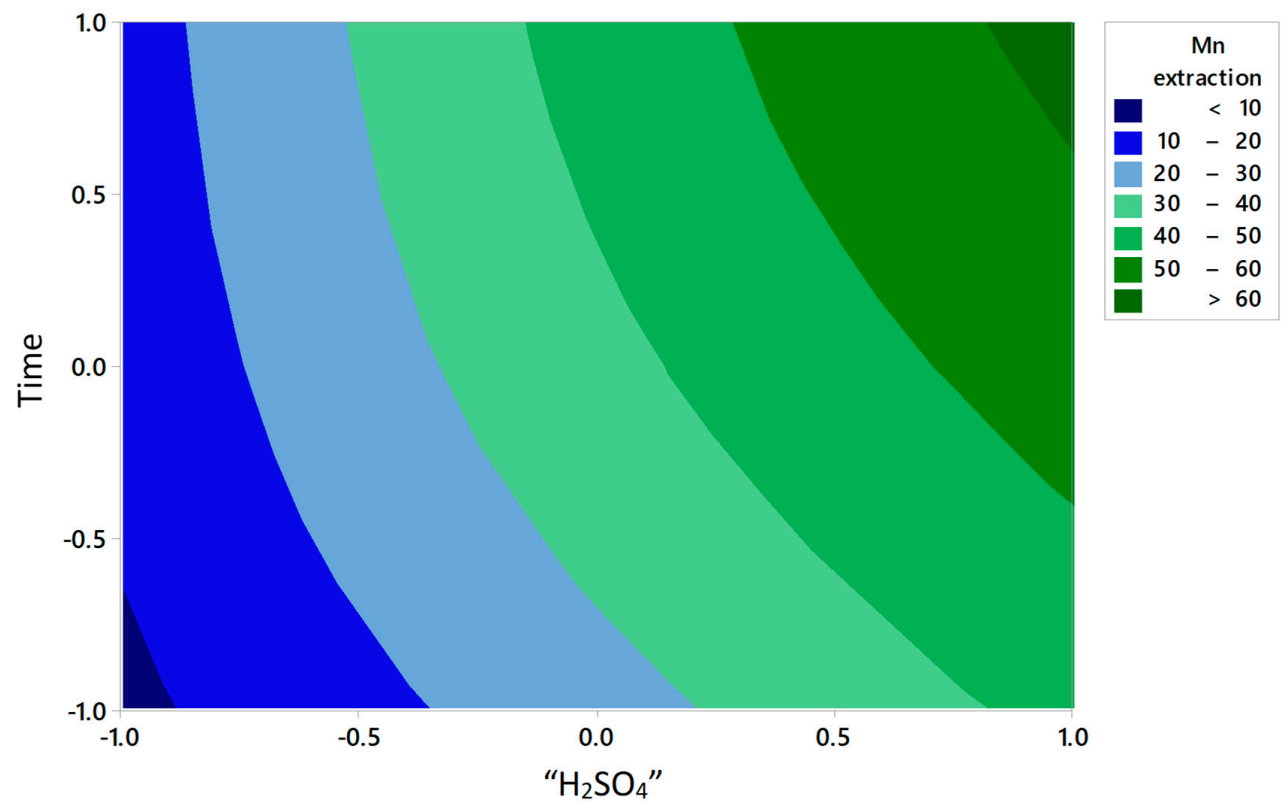

Figure 2. Experimental contour plot of Mn extraction $\left(25^{\circ} \mathrm{C},-100+140,-200+270,-320+400\right.$ sieve fraction mesh, 5, 10, 20, 30, 40 min leaching time, $\mathrm{H}_{2} \mathrm{SO}_{4} 0.1,0.5,0.75,1 \mathrm{M}$ and $1 \mathrm{MnO}_{2} / \mathrm{Fe} \mathrm{M}$ ratio).

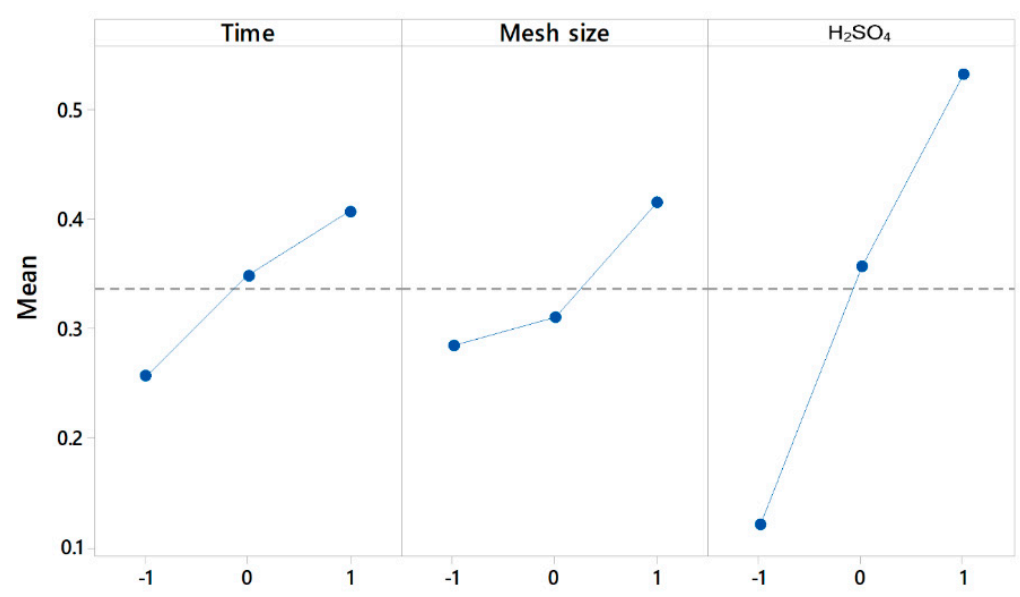

Figure 3. Linear effect plot for Mn extraction.

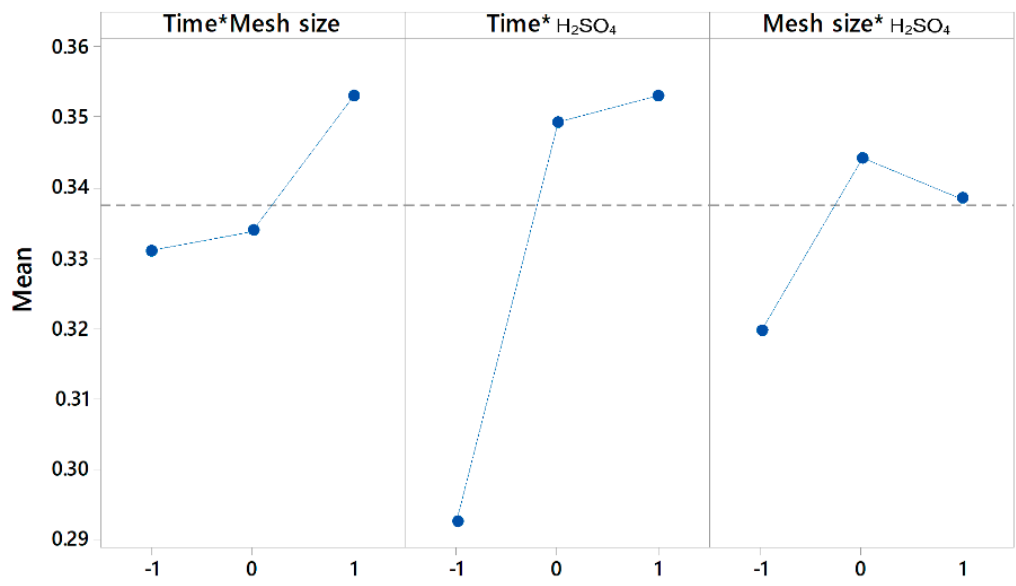

Figure 4. Interaction effect plot for Mn extraction. 


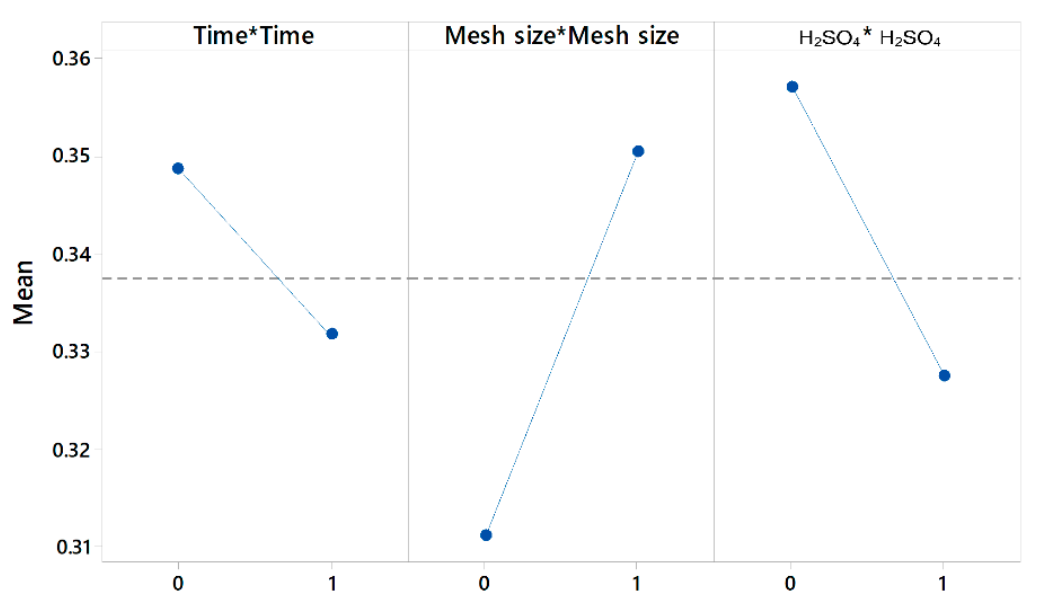

Figure 5. Curvature effect plot for Mn extraction.

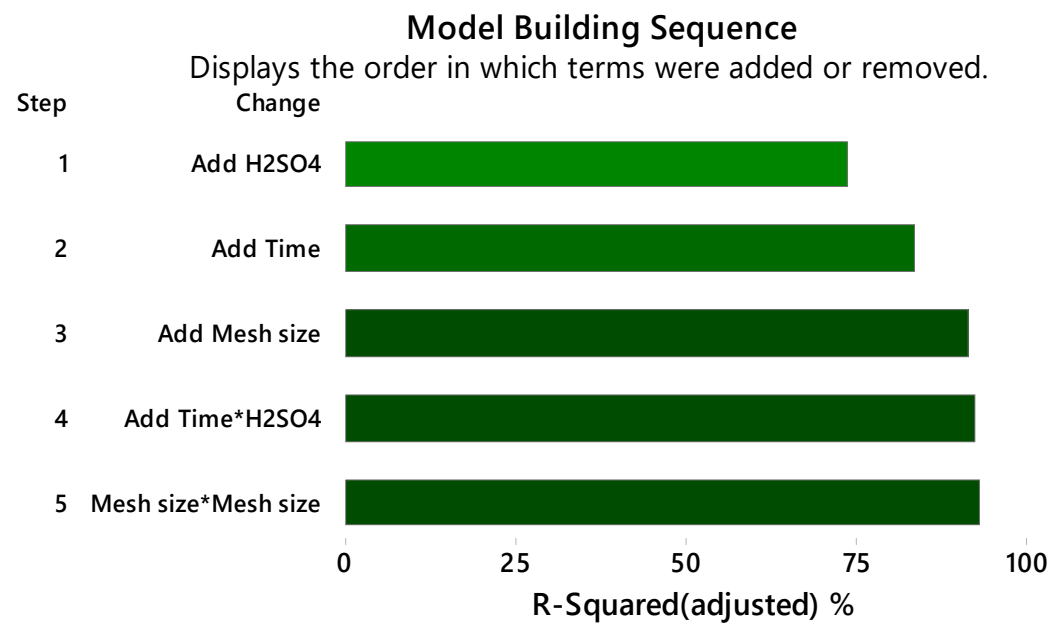

Figure 6. Construction sequence of the model.

An ANOVA test indicated that the quadratic model adequately represented Mn extraction under the established parameter ranges. The model did not require adjustment and it was validated by the $\mathrm{R}^{2}$ value (94.34\%) (Figure 7). The ANOVA analysis showed that the indicated factors influenced the manganese extraction from regression (70.07), 5\% confidence level F4.22 (2.8167).

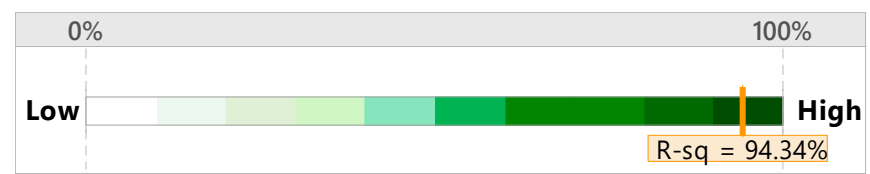

94.34\% of the variation in $Y$ can be explained by the regression model.

Figure 7. $\mathrm{R}^{2}$ statistic with \% of variation explained by the model.

The $p$ value (Figure 8) of the model, as represented by Equation (12), indicated that the model was statistically significant.

The Mallows's Cp indicated that the model was relatively accurate and did not present bias in estimating the true regression coefficients. It also allows for prediction with an acceptable future forecast margin of error of $R_{\text {pred }}=91.13 \%$. The response surface graphs in Figure 9A show that $\mathrm{Mn}$ extraction increased with a larger particle size and higher $\mathrm{H}_{2} \mathrm{SO}_{4}$ concentration. Figure $9 \mathrm{~B}$ shows the effect of increased time and $\mathrm{H}_{2} \mathrm{SO}_{4}$ concentration, which significantly increased extraction. Finally, 
Figure $9 \mathrm{C}$ shows that Mn extraction increased with increased mesh size and time, in the context of the size parameters used in the experiment.

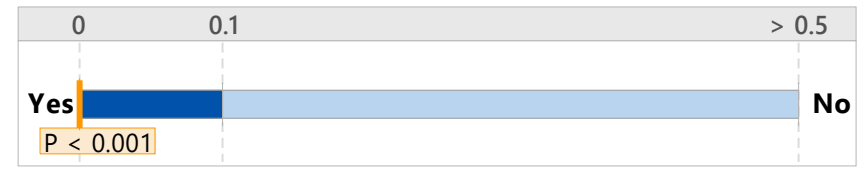

The relationship between $\mathrm{Y}$ and the $\mathrm{X}$ variables in the model is statistically significant $(p<0.10)$.

Figure 8. $\mathrm{p}$ statistic of the relationship between the $\mathrm{Y}$ and $\mathrm{X}$ variables in the model.

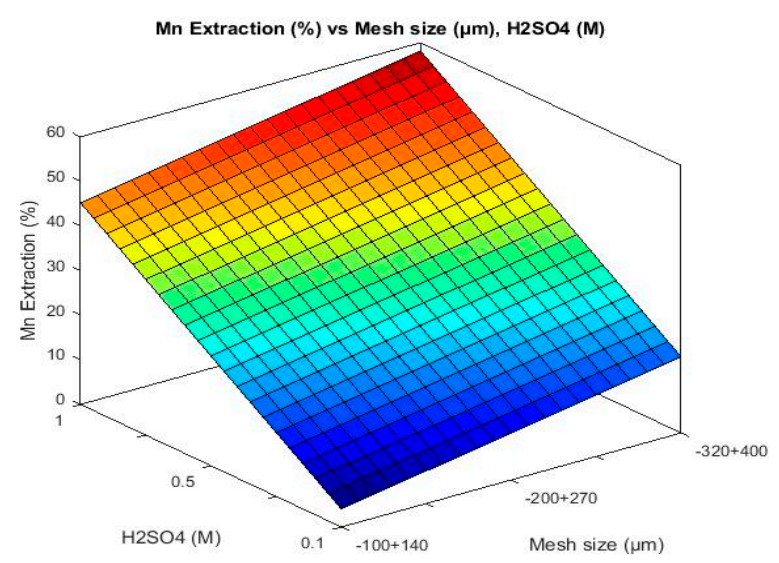

(A)

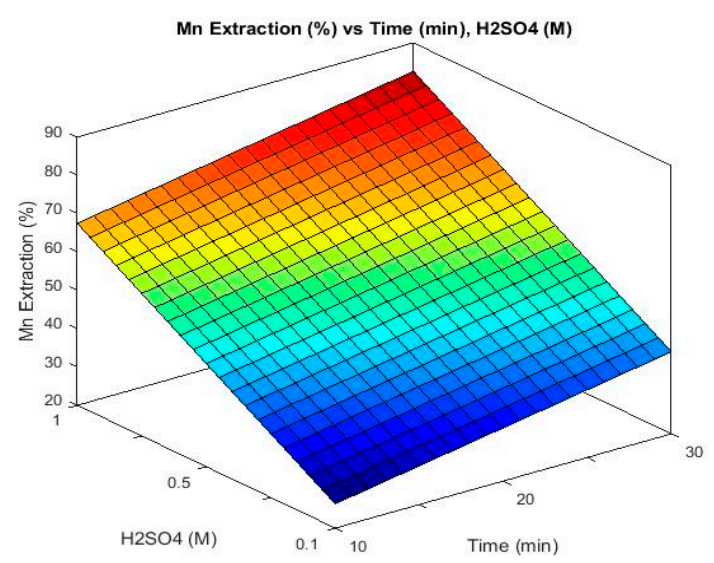

(B)

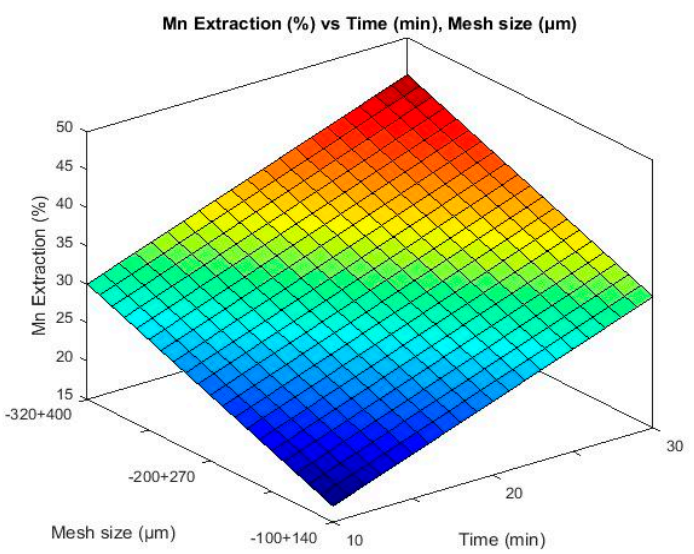

(C)

Figure 9. Response surface of the independent variables $\mathrm{H}_{2} \mathrm{SO}_{4}$ concentration and particle size (A), $\mathrm{H}_{2} \mathrm{SO}_{4}$ concentration and time (B), particle size and time, in the dependent variable Mn extraction (C).

Finally, from the adjustment of the ANOVA analysis, it was found that the factors considered, after analysis of the main components, explained the variation in the response. The difference between the predictive $\mathrm{R}^{2}$ and $\mathrm{R}^{2}$ of the model was minimal, thus reducing the risk that the model was over adjusted, that is, the probability that the model fits only the sample data is lower. The ANOVA analysis indicated that $\mathrm{H}_{2} \mathrm{SO}_{4}$, time, size and curvature of the mesh are the factors that explain to a greater extent the behavior of the system for the sampled data set.

\subsection{Effect of the $\mathrm{MnO}_{2} / \mathrm{Fe}$ Ratio}

The results shown in Figure 10 indicate that the Mn extraction rates increased with higher Fe concentrations, which concurs with the conclusions of Zakeri et al. [6] and Bafghi et al. [8]. The highest $\mathrm{Mn}$ extraction rates were obtained with a $\mathrm{MnO}_{2} / \mathrm{Fe}$ ratio of $1 / 2$. However, the extraction did not tend 
to increase much with time. It was emphasized that this $\mathrm{MnO}_{2} / \mathrm{Fe}$ ratio $1 / 2$ resulted in high extraction rates in short periods of time, such as $68 \% \mathrm{Mn}$ extraction in only $5 \mathrm{~min}$; by decreasing the $\mathrm{MnO}_{2} / \mathrm{Fe}$ ratio to $1 / 1$, it was possible to obtain an $\mathrm{Mn}$ extraction rate of $70 \%$ in $30 \mathrm{~min}$. The same tendency was noted with a 0.5 ratio, where there was a small extraction rate at $40 \mathrm{~min}$, and the extraction rates were lower with shorter periods of time $(5,10 \mathrm{~min})$. A low extraction rate of $47 \%$ in $40 \mathrm{~min}$ was obtained with an $\mathrm{MnO}_{2} / \mathrm{Fe}$ ratio of 2/1. The leaching results support the principle of dissolution using two rate-balancing corrosion couples, $\mathrm{MnO}_{2} / \mathrm{Fe}^{2+}$ and $\mathrm{FeS}_{2} / \mathrm{Fe}^{3+}$, and form the theoretical background [28]. Zakeri et al. [6] obtained better results during the leaching of $\mathrm{Mn}$ from marine nodules using iron instead of ferrous sulphate. This is because the iron in the system maintains ferrous ion regeneration, resulting in high levels of ferrous ion and ferric ion activity [8]. Under the ranges of $\mathrm{pH}(-2$ to 0.1$)$ and potential ( -0.4 to 1.4$), \mathrm{Mn}$ ions remain in solution and do not precipitate through oxidation-reduction reactions, given the presence of ions $\mathrm{Fe}^{2+}$ and $\mathrm{Fe}^{3+}$ [29]. Based on the positive results shown in Figure 10, slag is a viable reducing agent for Mn dissolution from marine nodules.

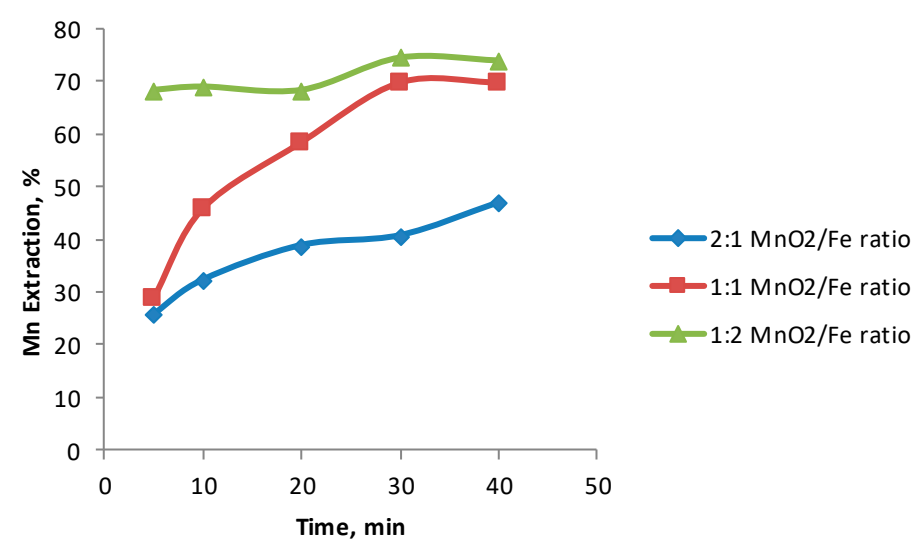

Figure 10. Effect of the $\mathrm{MnO}_{2} / \mathrm{Fe}$ ratio on manganese extraction $\left(25{ }^{\circ} \mathrm{C},-200+270\right.$ Tyler mesh $\left.(-75+53 \mu \mathrm{m}), \mathrm{H}_{2} \mathrm{SO}_{4} 1 \mathrm{M}\right)$.

\subsection{Effect of Particle Size}

Figure 11 shows that the effect of particle size on Mn extraction was not as significant as the effect of sulfuric acid concentration. Particle size is important in the context of a sulfuric acid concentration of $1 \mathrm{M}$. The highest Mn extraction rate of $70 \%$ was obtained for particle sizes between $-320+400$ Tyler $(-47+38 \mu \mathrm{m})$ mesh and an $\mathrm{H}_{2} \mathrm{SO}_{4}$ concentration of $1 \mathrm{M}$ (Figure 11B). However, a similar result, with a $65 \%$ extraction rate, was obtained with the same parameters and sizes ranging between $-200+270$ Tyler mesh $(-75+53 \mu \mathrm{m})$ (Figure 11C). The lowest extraction rate $(60 \%)$ was obtained for particle sizes between $-150+106 \mu \mathrm{m}$ and $1 \mathrm{M} \mathrm{H}_{2} \mathrm{SO}_{4}$ (Figure 11A).

Figure $11 \mathrm{C}$ shows that $\mathrm{Mn}$ extraction rates are lower with higher $\mathrm{H}_{2} \mathrm{SO}_{4}$ concentrations. Extraction did not exceed $3 \%$ with $\mathrm{H}_{2} \mathrm{SO}_{4}$ concentrations of $0.5,0.75$ and $1 \mathrm{M}$. The results obtained in this research (Figures 10 and 11) indicate the promising use of an industrial waste in dissolving Mn from marine nodules. There is a need for additional research to overcome production barriers and provide technological alternatives as a viable option for extracting metals from raw materials [30]. Reusing smelter slag in element extraction also produces considerable savings in disposal costs and reduces environmental impacts, which can result in greater social acceptance of the industry. 


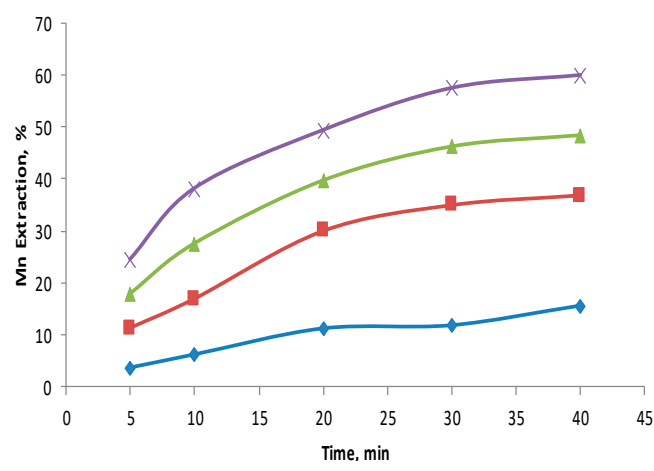

(A)
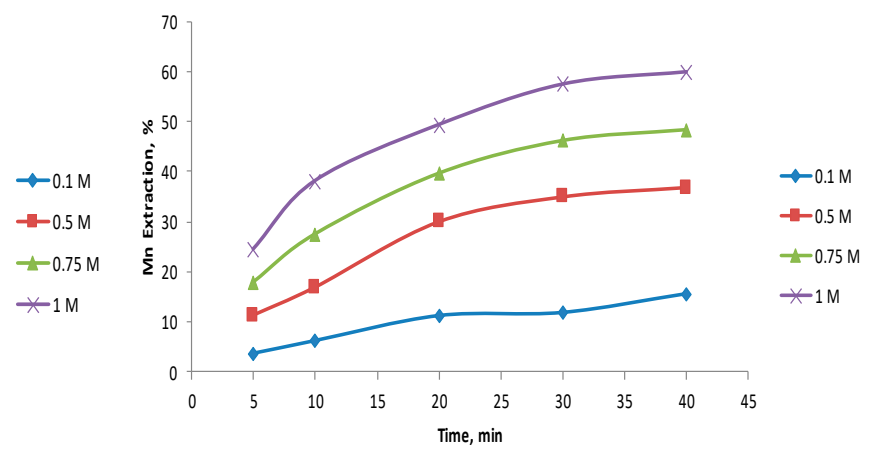

(B)

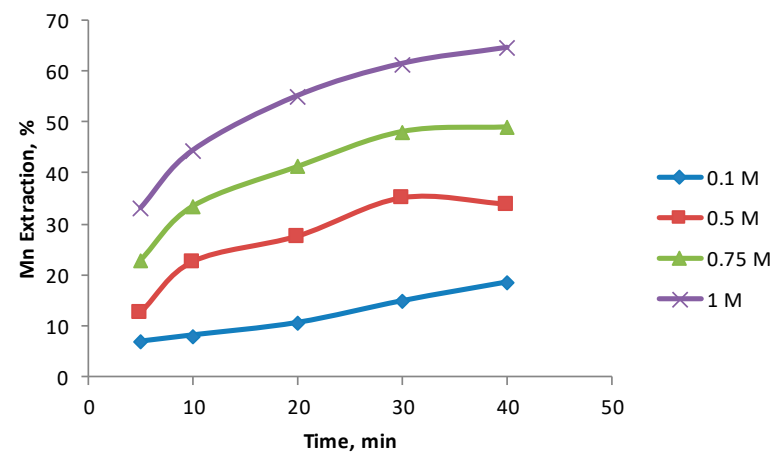

(C)

Figure 11. Effect of particle size (manganese nodule) on Mn extraction $\left(25^{\circ} \mathrm{C}, \mathrm{H}_{2} \mathrm{SO}_{4}: 0.1,0.5,0.75,1 \mathrm{M}\right)$. (A): $-100+140$ Tyler mesh $(-150+106 \mu \mathrm{m}),(\mathbf{B}):-200+270$ Tyler mesh $(-75+53 \mu \mathrm{m}),(\mathbf{C}):-320+400$ Tyler mesh $(-47+38 \mu \mathrm{m})$.

\section{Conclusions}

The present investigation presents the laboratory results for dissolving Mn from marine nodules in an acid medium at room temperature $\left(25^{\circ} \mathrm{C}\right)$ with the use of foundry slag. The iron metal proved to be a good reducer when leaching $\mathrm{MnO}_{2}$ in acid media. The findings of this study were:

(1) High ratios of $\mathrm{MnO}_{2} / \mathrm{Fe}(0.5)$ and $1 \mathrm{M} \mathrm{H}_{2} \mathrm{SO}_{4}$ significantly shorten the manganese dissolution time (from 30 to $5 \mathrm{~min}$ ).

(2) The $\mathrm{MnO}_{2}$ particle size is not as significant for the extraction of $\mathrm{Mn}$ in solution as the concentration of $\mathrm{H}_{2} \mathrm{SO}_{4}$ in the presence of Fe from foundry slag.

(3) At low granulometries $(-47+38 \mu \mathrm{m})$ the Mn extraction margins were narrower when higher $\mathrm{H}_{2} \mathrm{SO}_{4}$ concentrations were used.

(4) The highest $\mathrm{Mn}$ extraction obtained in this experimental study at a $\mathrm{MnO}_{2}$ ratio of $0.5,1 \mathrm{M}$ $\mathrm{H}_{2} \mathrm{SO}_{4},-320+400$ Tyler mesh $(-47+38 \mu \mathrm{m})$, with 30 min of leaching was $61.4 \%$.

Author Contributions: N.T., C.M.T., N.H. contributed in the methodology, conceived and designed the experiments; analyzed the data and wrote paper, J.C. and R.S. performed the experiments.

Funding: This research received no external funding.

Acknowledgments: The authors are grateful for the contribution of the Scientific Equipment Unit- MAINI of the Universidad Católica del Norte for aiding in generating data by automated electronic microscopy QEMSCAN $^{\circledR}$ and for facilitating the chemical analysis of the solutions. We are also grateful to the Altonorte Mining Company for supporting this research and providing slag for this study, and we thank the students Reina Valdés Marangunic, Kevin Pérez Salinas and Manuel Saldaña Pino of the Universidad Católica del Norte for supporting the experimental tests. FCAC 2018-UCN contributed reagents/materials/analysis tools.

Conflicts of Interest: The authors declare no conflict of interest. 


\section{References}

1. Somoza, L.; González, F.; León, R.; Medialdea, T.; De Torres, T.; Ortiz, J.; Lunar, R.; Martínez-Frías, J.; Merinero, R. Ferromanganese nodules and micro-hardgrounds associated with the Cadiz Contourite Channel (NE Atlantic): Palaeoenvironmental records of fluid venting and bottom currents. Chem. Geol. 2012, 310-311, 56-78.

2. Senanayake, G. Acid leaching of metals from deep-sea manganese nodules-A critical review of fundamentals and applications. Miner. Eng. 2011, 24, 1379-1396. [CrossRef]

3. Lenoble, J.P. Polymetallic Nodules; International Seabed Authority: Kingston, Jamaica, 2000; p. 8.

4. Kanungo, S.B. Rate process of the reduction leaching of manganese nodules in dilute $\mathrm{HCl}$ in presence of pyrite. Part I. Dissolution behavior of iron and sulphur species during leaching. Hydrometallurgy 1999, 52, 313-330. [CrossRef]

5. Kanungo, S.B. Rate process of the reduction leaching of manganese nodules in dilute $\mathrm{HCl}$ in presence of pyrite: Part II. Leaching behavior of manganese. Hydrometallurgy 1999, 52, 331-347. [CrossRef]

6. Zakeri, A.; Bafghi, M.S.; Shahriari, S. Dissolution of manganese dioxide ore in sulfuric acid in the presence of ferrous ion. Iran. J. Mater. Sci. Engi. 2007, 4, 22-27.

7. Su, H.; Liu, H.; Wang, F.; Lü, X.; Wen, Y. Kinetics of Reductive Leaching of Low-grade Pyrolusite with Molasses Alcohol Wastewater in $\mathrm{H}_{2} \mathrm{SO}_{4}$. Chin. J. Chem. Eng. 2010, 18, 730-735. [CrossRef]

8. Bafghi, M.; Zakeri, A.; Ghasemi, Z.; Adeli, M. Reductive dissolution of manganese ore sulfuric acid in the presence of iron metal. Hydrometallurgy 2008, 90, 207-212. [CrossRef]

9. Kanungo, S.B.; Das, R.P. Extraction of metals from manganese nodules of the Indian Ocean by leaching in aqueous solution of sulphur dioxide. Hydrometallurgy 1988, 20, 135-146. [CrossRef]

10. Charewicz, W.A.; Chaoyin, Z.; Chmielewski, T. The leaching behavior of ocean polymetallic nodules in chloride solutions. Physicochem. Probl. Miner. Process. 2001, 35, 55-56.

11. Kanungo, S.B.; Jena, P.K. Reduction leaching of manganese nodules of Indian Ocean origin in dilute hydrochloric acid. Hydrometallurgy 1998, 2, 41-58. [CrossRef]

12. Han, K.N.; Fuerstenau, D.W. Acid leaching of ocean floor manganese nodules at elevated temperature. Int. J. Miner. Process. 1975, 2, 163-171. [CrossRef]

13. Jiang, T.; Yang, Y.; Huang, Z.; Zhang, B.; Qiu, G. Leaching kinetics of pyrolusite from manganese-silver ores in the presence of hydrogen peroxide. Hydrometallurgy 2004, 72, 129-138. [CrossRef]

14. Petrie, L.M. Molecular interpretation for $\mathrm{SO}_{2}$ dissolution kinetics of pyrolusite, manganite and hematite. Appl. Geochem. 1995, 10, 253-267. [CrossRef]

15. Nayl, A.A.; Ismail, I.M.; Aly, H.F. Recovery of pure $\mathrm{MnSO}_{4} \cdot \mathrm{H}_{2} \mathrm{O}$ by reductive leaching of manganese from pyrolusite ore by sulfuric acid and hydrogen peroxide. Int. J. Miner. Process. 2011, 100, 116-123. [CrossRef]

16. Hariprasad, D.; Mohapatra, M.; Anand, S. Non-isothermal self-sustained one pot dissolution of metal values from manganese nodules using $\mathrm{NH}_{3} \mathrm{OHCl}$ as a novel reductant in sulfuric acid medium. J. Chem. Technol. Biotechnol. 2013, 88, 1114-1120. [CrossRef]

17. White, F.; Peterson, M.L.; Hochella, M.F. Electrochemistry and dissolution kinetics of magnetite and ilmenite. Geochim. Cosmochim. Acta 1994, 58, 1859-1875. [CrossRef]

18. Nijjer, S.; Thonstad, J.; Haarberg, G.M. Oxidation of manganese(II) and reduction of manganese dioxide in sulphuric acid. Electrochim. Acta 2000, 46, 395-399. [CrossRef]

19. Godunov, E.B.; Izotov, A.D.; Gorichev, I.G. Reactions of manganese oxides with sulfuric acid solutions studied by kinetic and electrochemical methods. Inorg. Mater. 2017, 53, 831-837. [CrossRef]

20. Anacleto, N.; Ostrovski, O.; Ganguly, S. Reduction of Manganese Oxides by Methane-containing Gas. ISIJ Int. 2004, 44, 1480-1487. [CrossRef]

21. Sesen, F.E. Practical reduction of manganese oxide. J. Chem. Technol. Appl. 2017, 1, 1-2.

22. COCHILCO. Análisis del Catastro de Depósitos de Relaves en Chile y guía de estructura de datos. Servicio Nacional de Geología y Minería. 2018. Available online: http://www.sernageomin.cl/wp-content/ uploads/2018/05/An\%C3\%A1lisis-de-los-Dep\%C3\%B3sitos-de-Relaves-en-Chile_VF.pdf (accessed on 1 December 2018).

23. DGA 1998, Universidad de Chile. Informe País: Estado del Medio Ambiente en Chile 2012. 2013. Available online: http:/ / www.repositorio.uchile.cl/handle/2250/123564 (accessed on 1 December 2018).

24. Dean, A.; Voss, D.; Draguljic, D. Response Surface Methodology. Des. Anal. Exp. 2017, 565-614. 
25. Bezerra, M.A.; Santelli, R.E.; Oliveira, E.P.; Villar, L.S.; Escaleira, L.A. Response surface methodology (RSM) as a tool for optimization in analytical chemistry. Talanta 2008, 76, 965-977. [CrossRef] [PubMed]

26. Berger, P.D.; Maurer, R.E.; Celli, G.B. Multiple Linear Regression. In Experimental Design; Springer International Publishing: Cham, Switzerland, 2018; pp. 505-532.

27. Montgomery, D.C. Design and Analysis of Experiments; Wiley: Hoboken, NJ, USA, 2012; Volume 8, pp. 3-10.

28. Paramguru, R.K.; Kanungu, S.B. Electrochemical phenomena in $\mathrm{MnO}_{2}-\mathrm{FeS}_{2}$ leaching in dilute $\mathrm{HCl}$. Part 3. Manganese dissolution from indian ocean nodules. Can. Metall. Q. 1998, 37, 405-417. [CrossRef]

29. Komnitsas, K.; Bazdanis, G.; Bartzas, G.; Sahinkaya, E.; Zaharaki, D. Removal of heavy metals from leachates using organic/ inorganic permeable reactive barriers. Desalin. Water Treat. 2013, 51, 3052-3059. [CrossRef]

30. Komnitsas, K.; Zaharaki, D.; Perdikatsis, V. Effect of synthesis parameters on the compressive strength of low-calcium ferronickel slag inorganic polymers. J. Hazard. Mater. 2009, 161, 760-768. [CrossRef] [PubMed]

(C) 2018 by the authors. Licensee MDPI, Basel, Switzerland. This article is an open access article distributed under the terms and conditions of the Creative Commons Attribution (CC BY) license (http:/ / creativecommons.org/licenses/by/4.0/). 